INBSIR 78-1475

Alllul ?2ьь 33
Air Leakage Measurements in Three Apartment Houses in the Chicago Area

Charles M. Hunt

Building Thermal and Service Systems Division

Center for Building Technology

National Engineering Laboratory

National Bureau of Standards

Washington, D.C. 20234

John M. Porterfield

Energy Resources Center

University of Illinois at Chicago Circle

Paul Ondris

University of Illinois at Chicago Circle

Chicago, Illinois 60680

June 1978

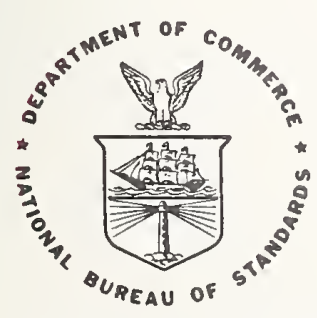

DEPARTMENT OF COMMERCE

- QC TNAL BUREAU OF STANDARDS

100

.456

78-1475 


\section{AIR LEAKAGE MEASUREMENTS IN THREE APARTMENT HOUSES IN THE CHICAGO AREA}

Charles M. Hunt

Building Thermal and Service Systems Division Center for Building Technology National Engineering Laboratory National Bureau of Standards

Washington, D.C. 20234

John M. Porterfield

Energy Resources Center

University of Illinois at Chicago Circle

Paul Ondris

University of Illinois at Chicago Circle

Chicago, Illinois 60680

June 1978

U.S. DEPARTMENT OF COMMERCE, Juanita M. Kreps, Secretary

Dr. Sidney Harman, Under Secretary

Jordan J. Baruch. Assistant Secretary for Science and Technology

NATIONAL BUREAU OF STANDARDS, Ernest Ambler, Director 



\title{
AIR LEAKAGE MEASUREMENTS IN THREE APARTMENT \\ HOUSES IN THE CHICAGO AREA
}

\author{
by \\ Charles M. Hunt
Paul John Porterfield
Pals
}

Abstract

Air infiltration measurements were made in three apartment houses in the Chicago area using $\mathrm{SF}_{6}$ as a tracer gas. Two were in tenement districts and one was suburban. Data were collected in selected apartments in each building, and these data were used to estimate the infiltration rate for the entire building. Whole building estimates of 0.94 and 1.2 air changes per hour were obtained under the conditions of tests in the tenement apartments, and 0.82 air changes per hour in the suburban apartment.

Comparisons of the tightness of individual dwelling units by fan pressurizationdepressurization techniques were also made. The suburban apartment was found to be much tighter than the other two apartments. The difference was much greater than predicted by the tracer tests.

An analysis of the ASHRAE Crack Method is also made.

Key Words: Air infiltration, air leakage, sulfur hexafluoride tracer, low income housing.

1 Therma1 Engineering Section

Center for Building Technology

National Engineering Laboratory

National Bureau of Standards

2

Energy Resources Center

University of Illinois at Chicago Circle

3 University of Illinois at Chicago Circle 


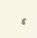




\section{INTRODUCTION}

Work has been undertaken on behalf of the Weatherization Program of the Community Services Administration to assess the effectiveness of various retrofit options aimed at reducing energy losses in housing for lower income people. A number of buildings have been selected for this study. The present report deals with air leakage measurement in three apartments of this group which were initially selected to represent tight, intermediate, and leaky buildings. This study is a joint effort of the National Bureau of Standards and the Energy Resources Center at the University of Illinois at Chicago Circle. While the measurements do not cover a wide range of weather conditions, and in this respect are limited in scope, they do provide information on types of housing for which little if any previous data are available. They provide a starting point for computer modeling of the infiltration component of energy consumption of the buildings.

\section{DESCRIPT ION OF BUILDINGS}

For purposes of identification the three apartment houses will be designated as Windsor, Kenmore, and Custer, these being the names of the streets on which they are located. Front views of the buildings are shown in Figures 1, 2, and 3. Floor plans of the dwelling units in which measurements were made are shown in Figures 4, 5 and 6 .

Windsor and Kenmore are in sections of the city which might be considered tenement areas while Custer is more suburban in location. Windsor was undergoing renovation when the tests were carried out, so that different apartments were in different degrees of repair, and many of them were unoccupied. This afforded an opportunity for experimentation which would be more difficult to achieve in occupied dwellings. Kenmore is comparable in size with Windsor, but it was fully occupied. It had also received earlier weatherstripping treatment, and doors into the hallways were better fitted. One of the reasons for including it in the measurements was to see if these improvements made a significant difference in air leakage characteristics. Presumably it was a tight building in comparison with Windsor.

Custer was a newer structure. It had swinging steel frame casement windows, while the other two apartments had double hung wooden sash windows. Custer also had concrete in its floor construction.

\section{INF ILTRATION TESTS}

Infiltration tests were made by the tracer gas dilution method using sulfur hexafluoride $\left(\mathrm{SF}_{6}\right)$ as the tracer gas. The particular apparatus used in these tests is similar to that described elsewhere [1,2], except that a chromatograph with a 6-port rotary sampling valve was used in place of one with a plunger-type valve. Also, the instrument response was linear instead of logarithmic as in the one previously described. 
Tracer gas was distributed throughout the dwelling space and its concentration measured as a function of time. Infiltration rate was calculated from the rate of disappearance of tracer gas by the relationship

$$
-\frac{\mathrm{dc}}{\mathrm{dt}}=\frac{\mathrm{v}}{\mathrm{v}} \mathrm{c}
$$

$$
\text { and } \quad-\ln \frac{\mathrm{c}}{\mathrm{c}_{\mathrm{o}}}=\frac{\mathrm{v}}{\mathrm{V}} \mathrm{t}=\mathrm{It}
$$

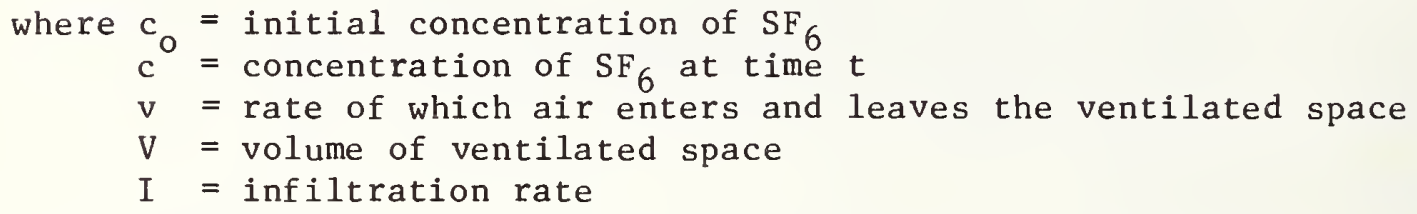

The natural logarithm of $\mathrm{c} / \mathrm{c}_{0}$ was plotted as a function of time, and by proper selection of units the slope of the line was equal to-I, where I=infiltration rate in air changes per hour.

\section{FAN PRESSURIZATION-DEPRESSURIZATION TESTS}

These tests were a modified and scaled down version of tests originally described by Cover [3], but recently improved and described more extensively by Tamura [4] and Stricker"[5]. An assembly consisting of an axial fan connected downstream from a commercial multi-port pitot-static flow measuring device was sealed into one of the doorways at each apartment under test. Fan speed was controlled by means of a variable transformer, and air was exhausted from the apartment. By reinstalling the assembly in the opposite direction the apartment could be pressurized. Differential pressure measurements were made between the inside and outside of selected dwelling units by means of a variable capacitance pressure gage with tubes leading inside and outside of the test-space. The same device was used to measure differential pressures across the pitot-static flow measuring device.

\section{INFILTRATION TESTS AT WINDSOR}

Before going into the tests themselves some problems involved in making tracer tests in buildings without central ducted ventilating systems should be mentioned. Without such a system in a multi-room, multi-story building there is no simple way to measure infiltration rate of the apartment house as a whole, so measurements were made in individual apartments, and projections as to what the infiltration rate should be for the entire building were made from these data. (A theoretical analysis of air movements in a multi-room building is given by Sinden [6].)

The first set of measurements at Windsor was made in the third floor north apartment. The floor plan and location of sampling points and fan is shown in Figure 4. Sufficient tracer gas was distributed throughout the space to produce a concentration of about 10-15 parts per billion ( $p p b)$. A fan with a delivery rate of about $800 \mathrm{cfm}$ was operated in the apartment to maintain mixing throughout each test. It was directed away from outside windows or doors so that air flow was not directed towards identified cracks. A fan was similarly used on the top floor 
but not on the second floor apartment because only two fans were available. Initially tracer gas was introduced only in this one apartment and concentration measurements made in this apartment. The apartments directly above and below were also checked for leakage of tracer into those areas, but none was found. Infiltration rates of 0.75 and 0.81 air changes per hour were obtained and are presented as the first two runs in Table 1.

Tracer gas was then distributed in the apartment above. This was a top-floor apartment. Higher infiltration rates were obtained than on the lower floor, as shown in Table 1.

In the remaining experiments tracer gas decay measurements were made with tracer gas in all three apartments, and finally in all three apartments plus the stairwell. If significant air leakage occurred from apartment to apartment, apparent infiltration rates would be correspondingly lower or higher depending on whether air entering from the rest of the building contained tracer gas or not. In this series of measurements, there was very little difference in infiltration rates on the third floor if the apartments below or above and the stairwell contained tracer gas. Even though there may have been some reduction in the calculated infiltration rate for the top floor when tracer gas was present in the apartment below and in the stairwell, these data suggest that the leakage paths were such that most of the air exchange was with the out-of-doors. If it is assumed that 0.83 air changes per hour is representative of the infiltration rates of the lower three floors and 1.25 represents the top floor, then the weighted average air exchange rate for windsor is 0.94 air changes per hour.

Wind data from O'Hare and Midway Airports indicated gusts as high as 15 to 20 knots at the time of the infiltration measurements. Some evidence of wind activity at the Windsor site was evident from the movement of tree branches and blowing of occasional bits of paper and light objects. However, the apartment building itself was surrounded by other buildings of comparable height which would alter wind patterns considerably. Wind data are presented here for descriptive purposes' only.

Temperature was measured by a single alcohol-in-glass thermometer outside on a shaded window ledge and another one centrally located indoors in the third floor apartment. Initial outside temperature was $50^{\circ} \mathrm{F}$ and inside $60^{\circ} \mathrm{F}$, and a temperature difference of approximately $10^{\circ} \mathrm{F}$ was maintained throughout the day as inside and outside temperatures increased. The low $\Delta \mathrm{T}$ would suggest that a less than normal stack effect was operating during the tests.

It was observed that tracer gas disappeared faster from the stairwell than from the dwelling units. This suggests there is significant air movement up the stairwell and out of the vent which is part of the skylight assembly. However, it is not certain how much this air leakage contributed to the leakage rates in the individual apartments. Tighter fitting of the doors leading into the stairwell might produce some reduction in air leakage. However, it might be noted that there are studies of houses which showed that leakage around windows and doors accounted for only a fraction of the total air leakage [4,7]. 
TABLE 1. INFILTRATION RATES AT WINDSOR, KENMORE, AND CUSTER

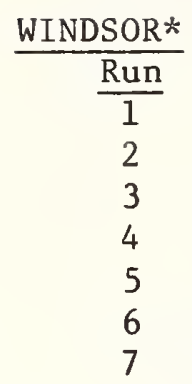

\section{Air Changes per Hour}

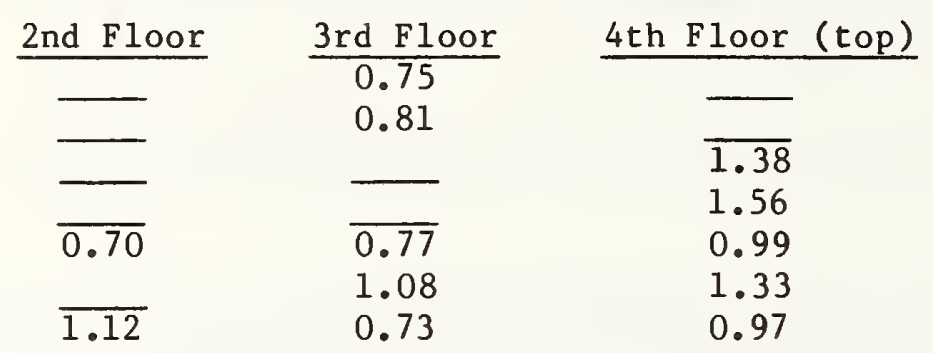

$$
\begin{aligned}
& \mathrm{SF}_{6} \text { added to } 3 \text { " } \\
& \mathrm{SF}_{.6} \text { added to } 4 \mathrm{th} \text { floor only } \\
& \mathrm{SF}_{6} \text { added to each apt. } \\
& \mathrm{SF}_{6} 6 \text { added to each apt. stairwell }
\end{aligned}
$$$$
\frac{3 \times .83+1.25}{4}=0.94
$$

1.25

0.14

0.25

$\frac{3 \text { rd Floor (top) }}{1.5}$

2nd Floor $\quad \frac{3 \text { rd Floor (top) }}{\square}$

Average

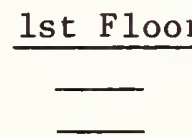

1.6

$$
1.6 \times \frac{.94}{1.25}=1.2
$$

CUSTER

$\begin{array}{ccc}\frac{\text { Run }}{1} & \frac{2 \text { 2nd Floor }}{0.72} & \frac{4 \text { th Floor (top) }}{1.05} \\ 2 & 0.77 & 1.05 \\ 3 & 0.78 & 0.86\end{array}$

$\begin{array}{lll}\text { Average } & 0.76 & 0.99 \\ \text { (SD) } & 0.03 & 0.11\end{array}$

$\frac{3 \times 0.76+0.99}{4}=0.82$

FThe floor entered nearest to ground level is designated as the lst floor.

\section{INFILTRATION TESTS AT KENMORE}

Tracer gas measurements were made in a top floor northside apartment at Kenmore. The floor plan is shown in Figure 5. Infiltration rates of 1.5 and 1.7 air change per hour were obtained. The results are included in Table 1 . Kenmore is presented in Table 1 as a three-floor apartment house. However it had a halfexposed basement and is treated as a four-story building like Windsor. Assuming an average rate of 1.6 air changes per hour and further assuming that the average air exchange rate for the apartment house was $75 \%$ of the rate for the top floor as at Windsor, a projected estimate of 1.2 air change per hour for the building is obtained.

As previously mentioned, Kenmore was selected as a tighter structure than Windsor because of caulking and weatherstripping. This prediction was not borne out by 
the infiltration measurement. However, no preretrofit data are available on the same building. Without such data it is difficult to accurately assess the effects of caulking and weatherstripping.

Fewer data were collected at Kenmore than originally intended because of greater problems encountered in working in occupied apartments than in vacant apartments. These include such things as occupants not home to permit access, invasion of privacy, doors or windows left open, certain rooms not accessible, etc.

Wind data indicated velocities of 10 knots at both Midway and 0 'Hara airports. Kenmore was also in a somewhat protected location. An outside temperature of $58^{\circ} \mathrm{F}$ and inside temperatures of 68 to $71^{\circ} \mathrm{F}$ were observed, so $\Delta \mathrm{T}$ was comparable with that observed at Windsor.

\section{INF ILTRATION MEASUREMENTS AT CUSTER}

Two apartments were measured at Custer. Both were in the south wing of the building. One was on the second floor. It was an interior apartment with exposures on the north and south. The other was an end apartment on the fourth floor with exposures on the north, south, and west. It appears on Figure 3 on the top floor at the right. Floor plans of the two apartments are also shown side-by-side in Figure 6. The average infiltration rate of the second floor apartment was 0.76 air changes per hour, and on the fourth floor 0.99 air changes per hour with a weighted average for the entire building of 0.82 air changes per hour, assuming that all but the top floor had an air exchange rate of 0.76 air changes per hour.

Wind velocities of 17 knots at Midway and 19 to 23 knots at $0^{\prime H a r e}$ were reported. An initial outside temperature of $72^{\circ} \mathrm{F}$ was observed, but this dropped to $52^{\circ} \mathrm{F}$ during tests indicating that a front passed through. Indoor temperatures were 80 to $82^{\circ} \mathrm{F}$ as measured in the second floor apartment.

The air infiltration rate was higher than anticipated from the comparative results of fan tests at Custer and Windsor which are to be described in a subsequent section of this report. A significant tracer gas concentration was always found in the stairwell, although none was added there, indicating a leakage under the front door and up the stairwell, as at Windsor. However, this leakage path was also present during the subsequent fan tests. No entirely satisfactory explanation is offered as to why this infiltration rate was higher than expected from the fan tests, but it is noted that Custer was in a more exposed location and the average insideoutside temperature difference was greater.

\section{PRESSURIZATION-DEPRESSURIZATION TESTS AT WINDSOR}

\subsection{COMPARISON OF DIFFERENT APARTMENTS}

Depressurization measurements were made in the second, third, and fourth floor apartments of Windsor. The purpose of this set of tests was to compare tightness of the second and third floor apartments, which had undergone renovations, with that of the fourth floor which was essentially in the run down state in which the owner had acquired it. In each measurement the low pressure lead was a 1/4-inch (id) polyethylene tube leading into the apartment. The outside lead ended in the stairwell far enough from the fan to avoid turbulence effects produced by the fan. The data are presented in a log-log graph in Figure 7. Very little difference is shown between the second and third floor apartments. The fourth 
floor does not fit the correlation for the other two floors, although most of the divergence lies in one point which is below the line. Since tracer gas measurements indicated the fourth floor to have a higher leakage rate than the other two floors, this is treated as an outlying point. While esthetically and functionally the renovated apartments were very different from the top floor apartment, they were not less permeable in the fan tests.

A fairly good argument could be made for the case that the higher infiltration rate of the fourth floor in tracer gas tests was due more to unrepaired leaks in the envelope structure than to its more exposed position. However, fan depressurization suggests that the top floor apartment was not more leaky than the others. This would favor the theory that the higher infiltration rate was primarily due to greater area of weather exposure on the top floor.

\subsection{EFFECT OF SEALING WINDOWS, DOORS, AND FIREPLACE}

A set of measurements were made in the third floor apartment with polyethylene film taped over each window and door frame so as to block the entire window or door except for leakages where the frames fit into the walls. The fireplace was also sealed. Pressurization was used on this set of measurements to reinforce the action of the tape rather than pull the film away from any openings as might occur with depressurization. The film and tape were than removed and the pressurization experiment repeated. The results are shown in Figure 8. The doors, windows, and fireplace did not account for more than 12 to $18 \%$ of the fan pressurization leakage. Since the measurements were made on an individual apartment rather than the building as a whole, the leakage through floors, ceilings and internal walls could represent a greater fraction of the total leakage than occurs in normal infiltration. If this were the case, leakage through windows and doors could account for more than 12 to $18 \%$ of the leakage through the external walls. However, Teitsma and Peavy [7] estimated that sealing of $f$ jalousie windows of a mobile home led to about an $18 \%$ decrease in leakage rate. In this case, pathways for internal leakages between different compartments of the building were minimal. Tamura [4] measured six houses and estimated that windows and doors represented about 15 to $24 \%$ of the total leakage paths. However, this data was obtained with storm windows and storm doors installed. Other tests indicated that leakage through the primary windows and doors was greater than 15 to $24 \%$.

It should also be noted that flow rates under conditions of pressurization were less than under depressurization. This may be seen by comparing Figures 7 and 8 .

\section{DEPRESSURIZATION MEASUREMENTS AT KENMORE}

Depressurization measurements at Kenmore were made in the second floor apartment on the north side of the building. The results are shown in Figure 9. They show air leakage rates slightly higher than those found at Windsor. This suggests that other parts of the apartment besides the weatherstripped windows and doors contributed to air leakage.

Measurements were not made on the top floor apartment where the tracer measurements were made, because the residents were out, and the apartment was not available when these tests were being made. 
Measurements were made in the second floor and the fourth floor apartments at Custer. In these tests the fan assembly was sealed to the rear door, and the outside pressure lead was conducted into the back stairwell. In addition, another type of test was made in the second floor apartment at Custer in which the windows were opened so that about 1/4-inch of daylight was visible between the window and the frame as illustrated in Figure 10. The purpose of this latter experiment was to see how much windows which leaked badly might contribute to the total leakage. The results are presented graphically in Figure 11. This slight opening of the windows nearly doubled the air leakage rate. Also the top floor apartment was slightly more leaky than the one in the second floor. This is qualitatively consistent with the results of the tracer measurements, unlike the results at Wind sor.

It is also of interest to note that the Custer apartment with the windows cracked open offered more resistance to air flow than the Windsor apartment with the windows and doors sealed. This large difference in building tightness was not fully reflected in the tracer measurements, but infiltration rates were slightly lower at Custer. Also, the Custer apartment was smaller so that for a given pressure difference about half the volume of air was flowing through the envelope as at Windsor.

It might be further noted that in fan tests pressures are applied symmetrically to all surfaces, and all flows are in or out depending on fan orientation. When single dwelling units are tested instead of the building as a whole, pressure differences across internal walls may be as great as across external walls. In normal infiltration pressure differences develop asymmetrically, and their magnitudes are typically less than those in fan tests. In any case, further analysis would be required to quantitatively account for the differences between Custer and Windsor in the tracer and fan tests.

11. COMPARISON OF FAN AND TRACER GAS TESTS

The results of selected fan tests are plotted in Figure 12. These include data from Windsor, Kenmore, and Custer as well as data from one other study [7]. The flow rates have been converted from $c$ fm to air changes per hour in order to compare them with tracer infiltration values. The solid squares in the figure represent infiltration rates by tracer measurements normalized to wind velocity of $10 \mathrm{mi} / \mathrm{hr}$ and inside-outside temperature difference of $10^{\circ} \mathrm{F}$. These are plotted against extrapolated estimates of the pressures which would be required to achieve the same air leakage rates by fan pressurization or depressurization. These pressures range from about 0.0003 to 0.002 in W.G.

This analysis assumes that the extrapolation is valid, and there is evidence that such log-log plots can be linear over a fairly wide range. It also assumes that under conditions of low wind perturbation integrated time-averaged pressure differences due to wind are negligible compared to fan-induced pressure differences.

1 Two of the seven windows were left closed, because they were difficult to operate. 
If these assumptions are correct, the results suggest that pressure differences required to induce natural infiltration may be much less 0.1 inches of water which is the lowest value for pressure induced air leakage through window cracks 1isted in the ASHRAE Book of Fundamentals [9]. In addition, the results in Figure 12 suggest that there is no simple extrapolation which will permit prediction of natural ventilation rates from fan pressurization measurements, which can be applied across the board to all.kinds of housing.

There are some differences between fan induced and natural air leakage which should be pointed out. In fan tests presumably all of the air is flowing into or out of the structure depending on fan orientation. If natural infiltration is treated as a simple "flow through" process, air may be considered to enter through half of the openings and leave through the other half. As evidenced by the straight line plots in Figure 12 as well many other examples, flow may be expressed by the relationship

$$
Q=\operatorname{kAp}^{n}
$$

where $Q=$ flow rate through crack

$k=$ flow constant

$A=$ area of cracks

$p=$ pressure difference across cracks

$\mathrm{n}=\mathrm{a}$ parameter having a typical value of about 0.6 in the present measur ements.

If the same flow rate is maintained, but through only half the area, the pressure differential would have to be about three times as large.

That is to say, if $A_{1}=0.5 A_{2}$,

$$
\begin{aligned}
& \mathrm{Q}_{1}=\mathrm{kA}_{1} \mathrm{P}_{1}^{\mathrm{n}} \\
& \mathrm{Q}_{2}=\mathrm{kA}_{2} \mathrm{P}_{2}^{\mathrm{n}}
\end{aligned}
$$

and

$$
\begin{aligned}
& \mathrm{Q}_{1}=\mathrm{Q}_{2} \\
& \mathrm{n}=0.6 \\
& \frac{\mathrm{P}_{1}}{-1}=\mathrm{A}_{2}^{1 / \mathrm{n}}=\mathrm{A}^{1 / 0.6}=3.17 . \\
& \mathrm{P}_{2}=\mathrm{A}_{1}
\end{aligned}
$$

Moreover, since air is assumed to enter through half of the cracks and exit through the other half, the two halves are in series, and the pressure difference is doubled. Therefore, it should be approximately six times as large, and instead of values 0.0003 to 0.002 , the simple "flow-through" model would call for pressures on the order of 0.002 to $0.012 \mathrm{in.W.G}$. The thermal head for a 10 degree temperature difference over a $10 \mathrm{ft}$. height would be of the order of $0.003 \mathrm{in}$. W.G. The calculated impact pressure of a $10 \mathrm{mi} / \mathrm{hr}$ wind is about $0.04 \mathrm{in}$. W.G. 
In addition to the question of how large the pressure difference is between the inside and outside of the building, a paper by Hill and Kusuda [8] introduces additional considerations. They measured infiltration rates in a closed room with a special window crack whose dimensions could be measured and controlled at will. They obtained experimental infiltration rates less than those calculated from measured average wind speed, particularly at velocities greater than $5 \mathrm{mi} / \mathrm{hr}$. They also measured pressure difference across the crack and showed that it had a strong pulsating component. This indicates that it is a great over-simplification to treat wind pressure as a simple steady state function. In their words, "the infiltration process that actually occurs in and around window cracks is an extremely complex one". The results in Figure 12 and in the subsequent analysis suggest that infiltration rates correspond to lower pressure differences than would be calculated from simple impact wind pressures.

\section{FLOW RATES PER UNIT AREA}

The lines in Figure 12 were extrapolated to a pressure difference of 0.3 in. W.G., converted to $\mathrm{cfm}$ and divided by the estimated area of the respective dwelling units. In this way the following estimates were obtained of flow rates expressed in $\mathrm{cfm} / \mathrm{ft}^{2}$ at 0.3 in. W. G.

$\begin{array}{lr}\text { Windsor } & 1.6 \\ \text { Kenmore } & 1.7 \\ \text { Custer } & .6,\end{array}$
or in $\frac{\mathrm{m}^{3} / \mathrm{s}}{\mathrm{m}^{2}}$ at $75 \mathrm{~Pa}$

Windsor $9.728 .1 \times 10^{-3}$ Kenmore $0.76 \quad 8.6 \times 10^{-3}$ Custer $0.2 \lambda 3.0 \times 10^{-3}$

These are estimates for individual dwelling units and not the building envelope. Most of the surface areas were interior walls, floors and ceilings.

\section{CALCULATION OF INFILTRATION AT WINDSOR BY THE CRACK METHOD}

Although fan pressurization tests indicated that the exposed cracks around windows and doors which would be included in a crack length survey do not account for all of the leakage paths in the apartment, an analysis of the crack method 19] for estimating infiltration is presented here. The lengths of cracks in the Windsor third floor apartment are itemized in Table 2.

TABLE 2. CRACK SURVEY AT WINDSOR THIRD-FLOOR APARTMENT

\begin{tabular}{|c|c|c|c|}
\hline & Multiple & & Footage \\
\hline $\begin{array}{l}\text { Crack at joints omitting windows "painted in" } \\
\text { at top sash. }\end{array}$ & 1.0 & $\mathrm{x}$ & 137.7 \\
\hline $\begin{array}{l}\text { Bed of frame at bottom or top where applicable } \\
\text { (see above). }\end{array}$ & 1.0 & $\mathrm{x}$ & 84.43 \\
\hline Cross strip (meeting of upper and lower sash). & 1.0 & $\mathrm{x}$ & 35.51 \\
\hline Threshold of doors. & 2.0 & $\mathrm{x}$ & 5.66 \\
\hline $\begin{array}{l}\text { Putty loose or missing (includes leaded glass } \\
\text { panes in upper sash). }\end{array}$ & 1.0 & $\mathrm{x}$ & 156.85 \\
\hline
\end{tabular}


If, for example, the value of $77 \mathrm{ft}^{3}$ per hour per foot of crack length is assumed, a total leakage of $32,800 \mathrm{ft}^{3} / \mathrm{h}$ is obtained, which corresponds to 3.7 airr changes per hour in the Windsor apartment, which has a volume of about $8,900 \mathrm{ft}^{3}$. This does not include leakage where the window frame is mounted in the wall. The value of 3.7 air changes per hour is more than four times the rate of 0.83 obtained by the tracer method. The flow rate of $77 \mathrm{ft}^{3}$ per foot of crack length comes from Table 2 in the ASHRAE Handbook [9] for double-hung windows, non-weatherstripped, loose fit. It corresponds to a pressure difference of 0.1 inch of water, the lowest pressure difference listed in the table. Actually, this use of the leakage rate corresponding to 0.1 inch of water is not specified in the ASHRAE Handbook, but it serves to point out that infiltration rates higher than the true rate can be obtained by assuming too high a pressure difference across windows and doors, even though these elements do not account for all of the leakage. The significantly higher air leakage determined by the crack method calculation in comparison with the measured value in the Windsor apartment could be due to erroneous assumptions of pressure difference, crack length, crack width, or a combination of these factors. The 1977 ASHRAE Handbook states, "Accuracy of the crack method for design load calculations is restricted by the limited data on air leakage characteristics and by the difficulty of estimating pressure differences under appropriate design conditions of temperature and wind." The results of these measurements would support this statement.

\section{SUMMARY}

The following average air leakage rates have been estimated from $\mathrm{SF}_{6}$ tracer measurements at three apartment buildings:

\begin{tabular}{|c|c|c|c|}
\hline & Average Ai & nges per Hour & \multirow{2}{*}{$\begin{array}{l}\text { Weighted } \\
\text { Average for } \\
\text { Entire Apt. } \\
\text { House } \\
\end{array}$} \\
\hline & $\begin{array}{l}\text { Top Floor } \\
\text { Apt. }\end{array}$ & $\begin{array}{l}\text { Lower Floor } \\
\text { Apt. }\end{array}$ & \\
\hline Wind sor & 1.25 & 0.83 & 0.94 \\
\hline Kenmore & 1.6 & $-\cdots-\infty$ & $\begin{array}{l}1.2 \text { (assumed } 75 \% \text { of value } \\
\text { for top floor.) }\end{array}$ \\
\hline
\end{tabular}

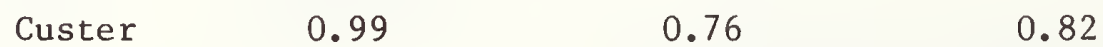

At Windsor and Kenmore inside-outside temperature difference was about $10^{\circ} \mathrm{F}$. At Custer it started at about $4^{\circ} \mathrm{F}$ and increased to about $30^{\circ} \mathrm{F}$ during the tests.

Fan pressurization-depressurization measurements indicated Kenmore to have a very slightly higher leakage rate than Windsor, while Custer was indicated to be much tighter than either of the other two.

Sealing all of the exposed areas of the windows, one door, and one fireplace at Windsor with polyethylene film produced at most a $20 \%$ reduction in air leakage rate measured by fan pressurization. However, the total leakage may have included pathways through internal walls plus floor and ceiling, as well as through outside 
wa11s. Custer offered more resistance to air flow, with windows cracked open slightly, than Windsor with windows and doors sealed. These results, plus the observations of others, indicate that leakage around windows and doors represents only part of the total air leakage paths in most buildings.

An analysis was made which suggests that experimental infiltration rates are intrinsically less than would be predicted from the simple impact pressure due to wind.

Analysis of the ASHRAE crack method suggests that it underestimates the number of leakage paths, but in applying the method results may be obtained which are plausible or even too high, if pressure difference across the cracks is overestimated.

\section{SI CONVERSIONS}

Familiar English units have been used in this report. To convert to units the following conversion factors are provided:

$$
\begin{array}{rlrl}
(\mathrm{cfm}) \times 4.719 \times 10^{-4} & =\left(\mathrm{m}^{3} / \mathrm{sec}\right) \\
(\mathrm{mi} / \mathrm{hr}) \times 0.44704 & =(\mathrm{m} / \mathrm{sec}) \\
\text { knots } \times 0.51444 & =(\mathrm{m} / \mathrm{sec}) \\
(\text { in. W. G. }) \times 249.1 & =(\mathrm{Pa}) \\
\text { in. } \times 0.025400 & =\mathrm{m} \\
\left({ }^{\circ} \mathrm{F}-32\right)_{\frac{5}{9}} & & ={ }^{\circ} \mathrm{C}
\end{array}
$$

\section{REFERENCES}

1. D. T. Harrje, C. M. Hunt, S. J. Treado, and N. J. Malek. Automated Instrumentation for Air Infiltration Measurements in Buildings, Center for Environmental Studies Report No. 13, Apri1 1975. (Princeton U.).

2. C. M. Hunt and S. J. Treado, A Prototype Semi-Automated System for Measuring Air Infiltration in Buildings Using Sulfur Hexafluoride as a Tracer, National Bureau of Standards Technical Note 898, March 1976.

3. L. E. Cover, Modern Insulation Methods. Two papers presented before the Institute of American Meat Packers, Copyright 1929.

4. G. T. Tamura, Measurement of Air Leakage Characteristics of House Enclosures, ASHRAE Trans. 81 (1), 202-211 (1975). 
5. S. Stricker, Measurement of Air-Tightness of Houses, ASHRAE Trans. 81 (1), 148-167 (1975).

6. F. W. Sinden, Multi-Chamber Theory of Air Infiltration. To be published in Vol. 12 of Buildings and Environment (1978), Pergamon Press.

7. G. J. Teitsma and B. A. Peavy, The Thermal Performance of a Two-Bedroom Mobile Home. National Bureau of Standards, Building Science Series 102 (1978).

8. J. E. Hil1 and T. Kusuda, Dynamic Characteristics of Air Infiltration, ASHRAE Transactions 81 (1), 168-185 (1975).

9. ASHRAE Handbook of Fundamentals, American Society of Heating, Refrigerating and Air-Conditioning Engineers (1977), Chapter 21. 


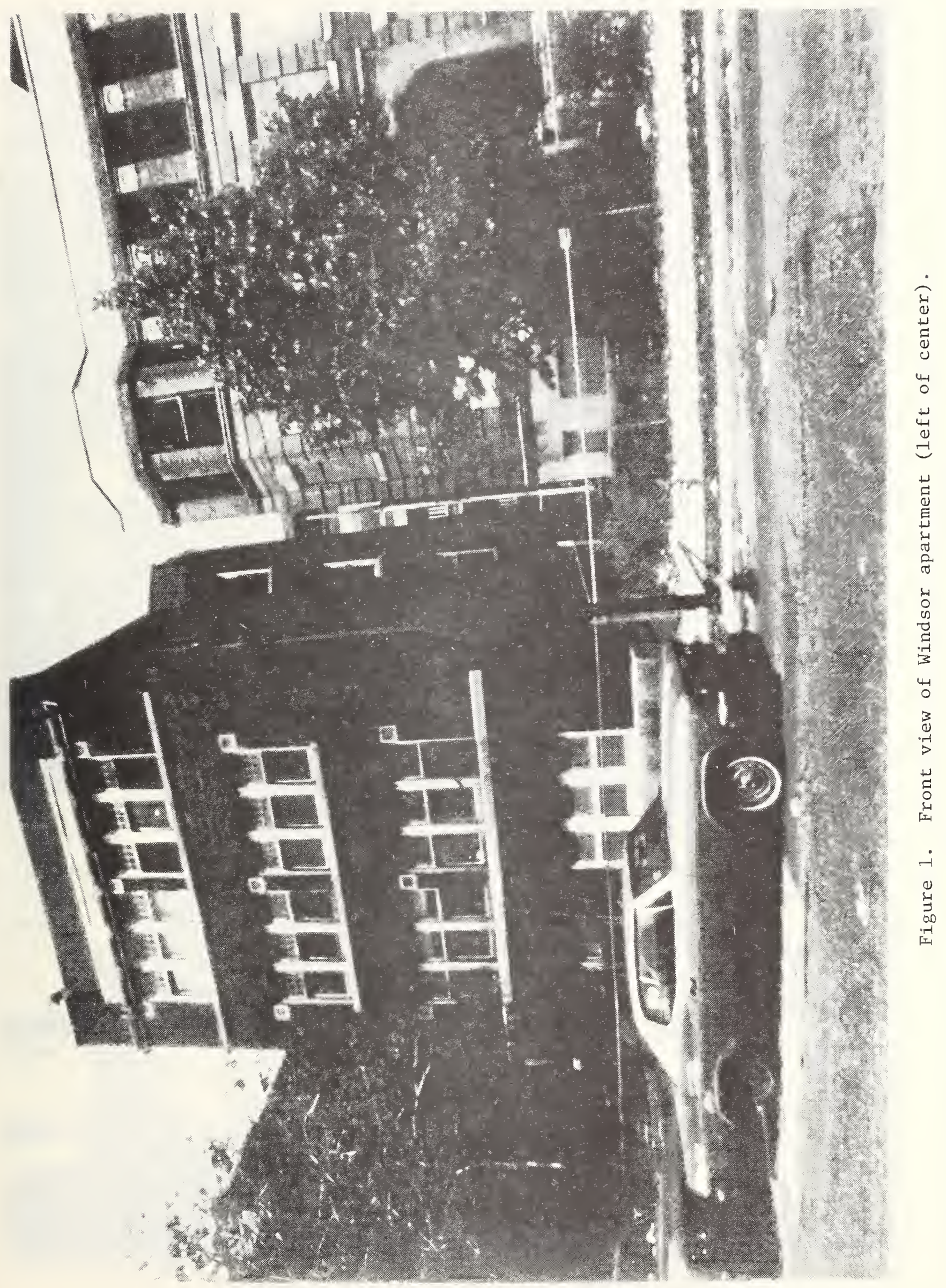




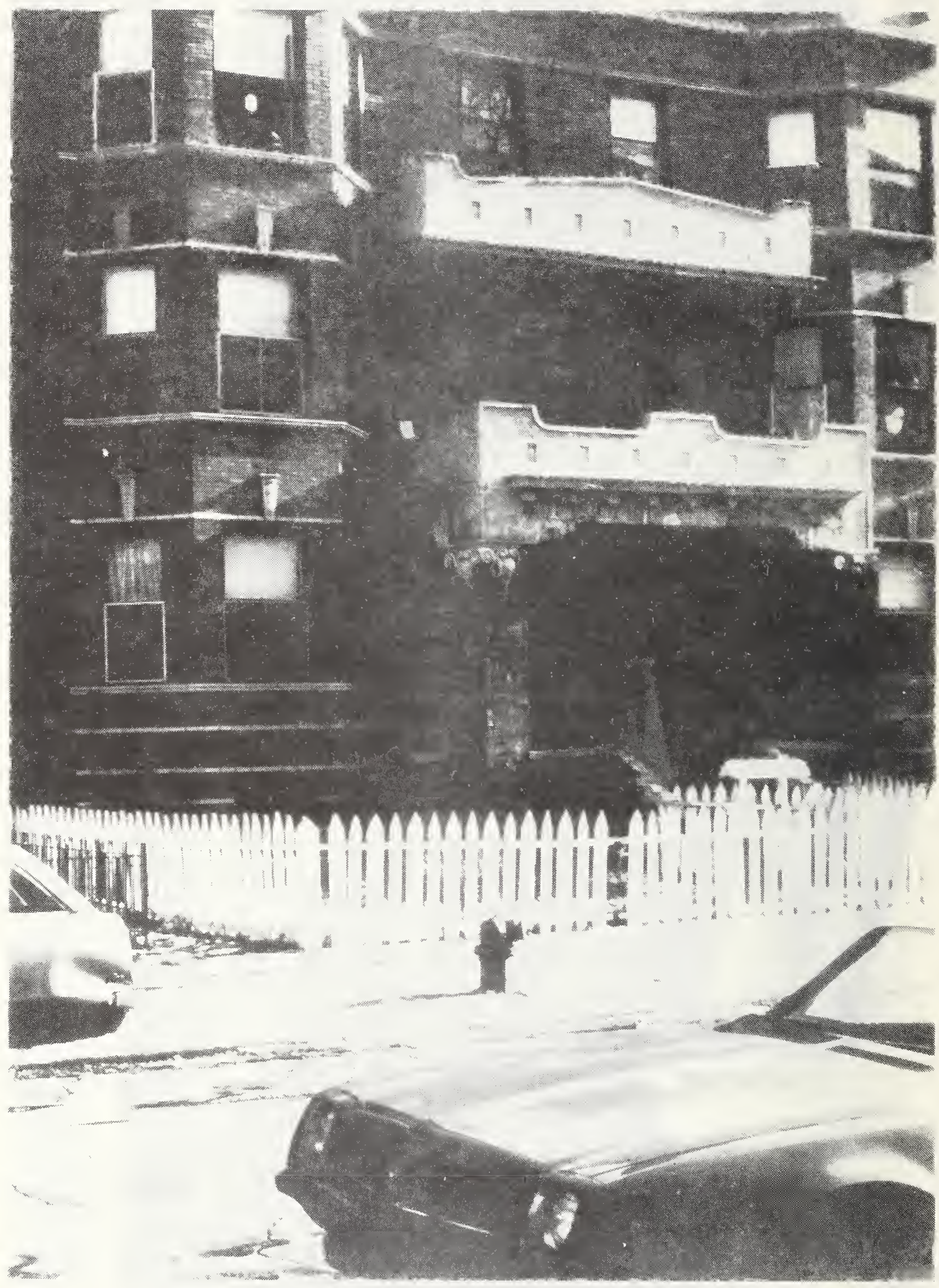

Figure 2. Front view of Kenmore apartment. 


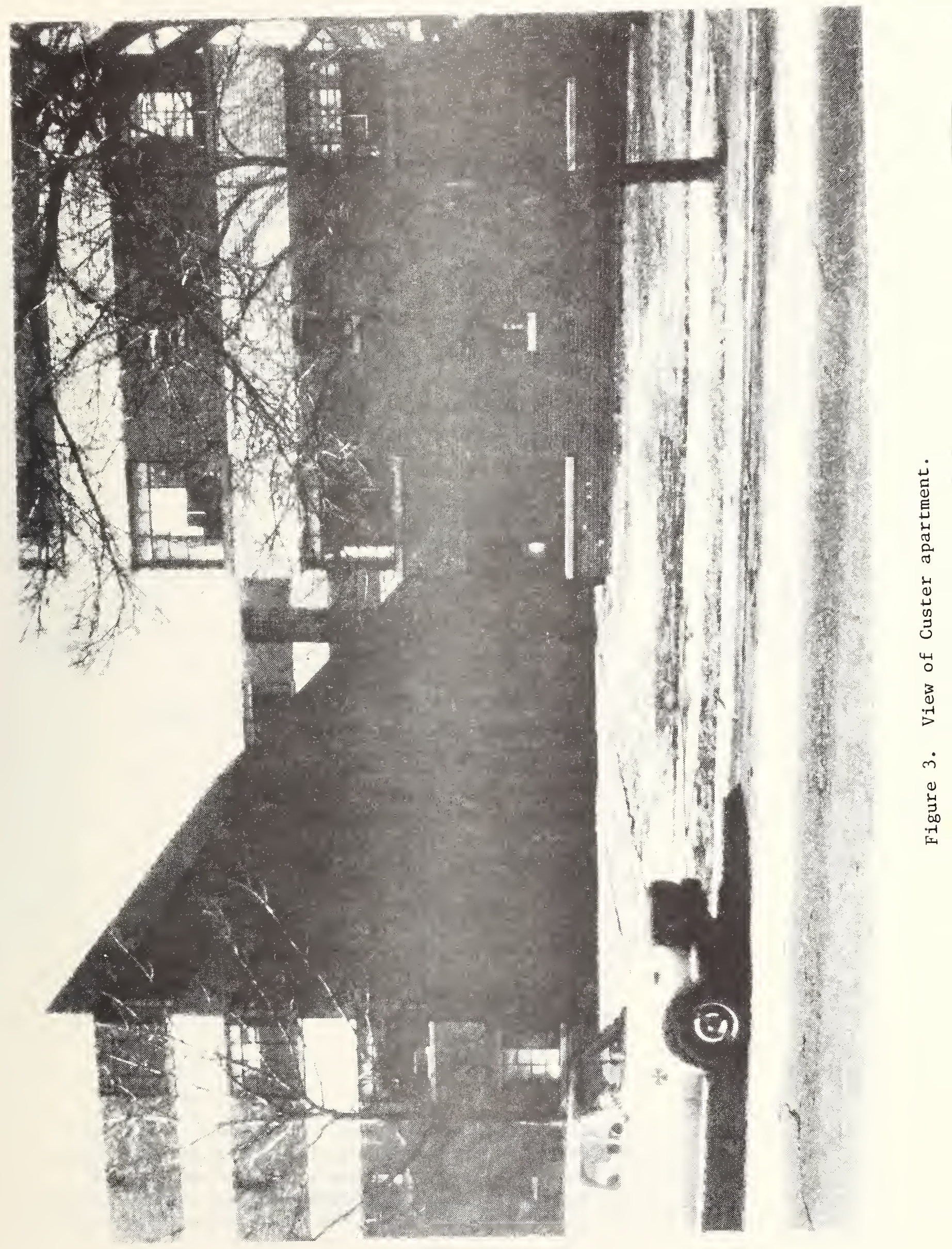




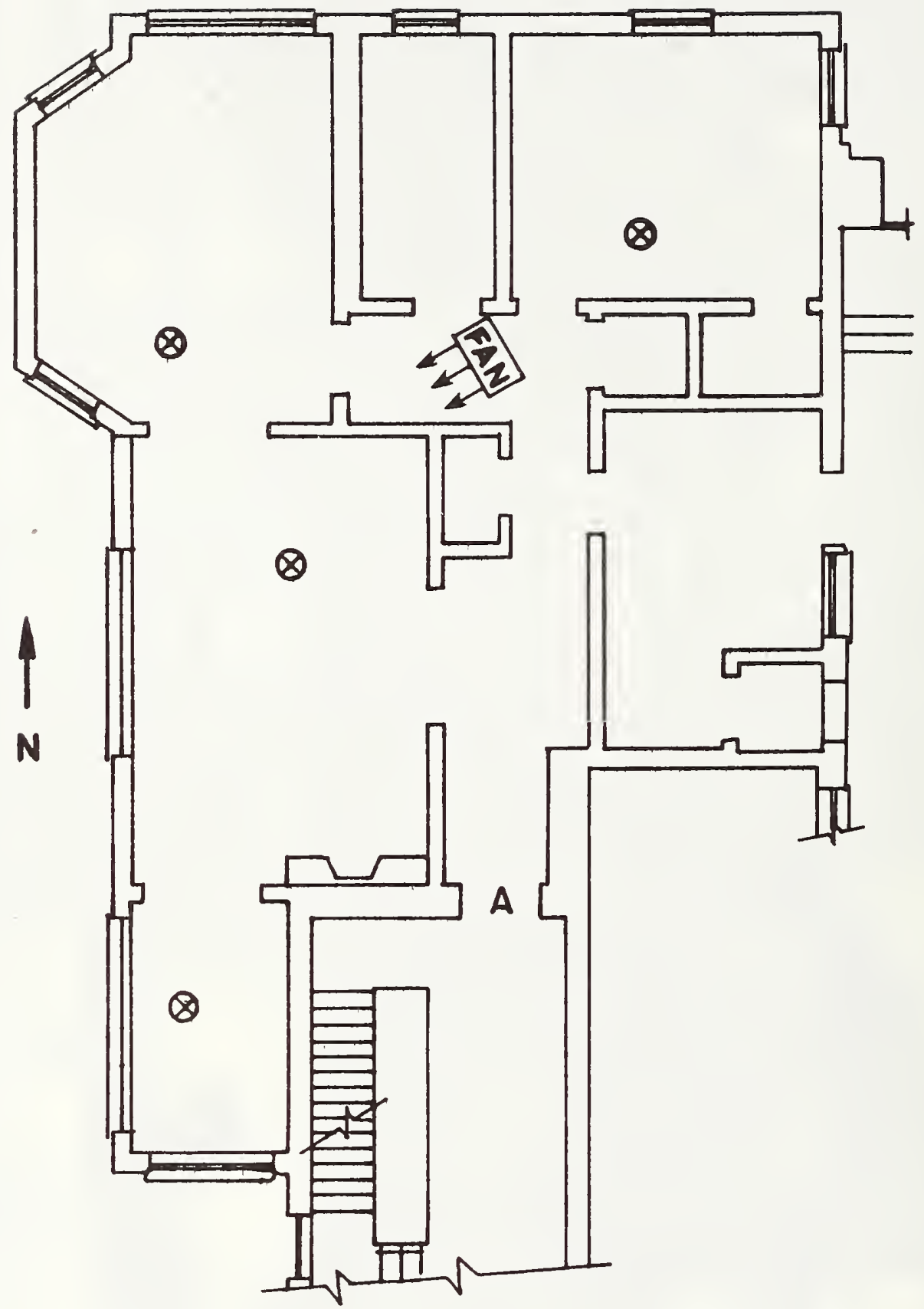

Figure 4. Floor plan of third-floor apartment at Windsor. Units on second and fourth floorshave essentially the same floor plan. Location of circulating fan is shown, and circled crosses show locations of air-sampling points. " $A$ " denotes location of high-speed fan used in pressurization-depressurization tests. 


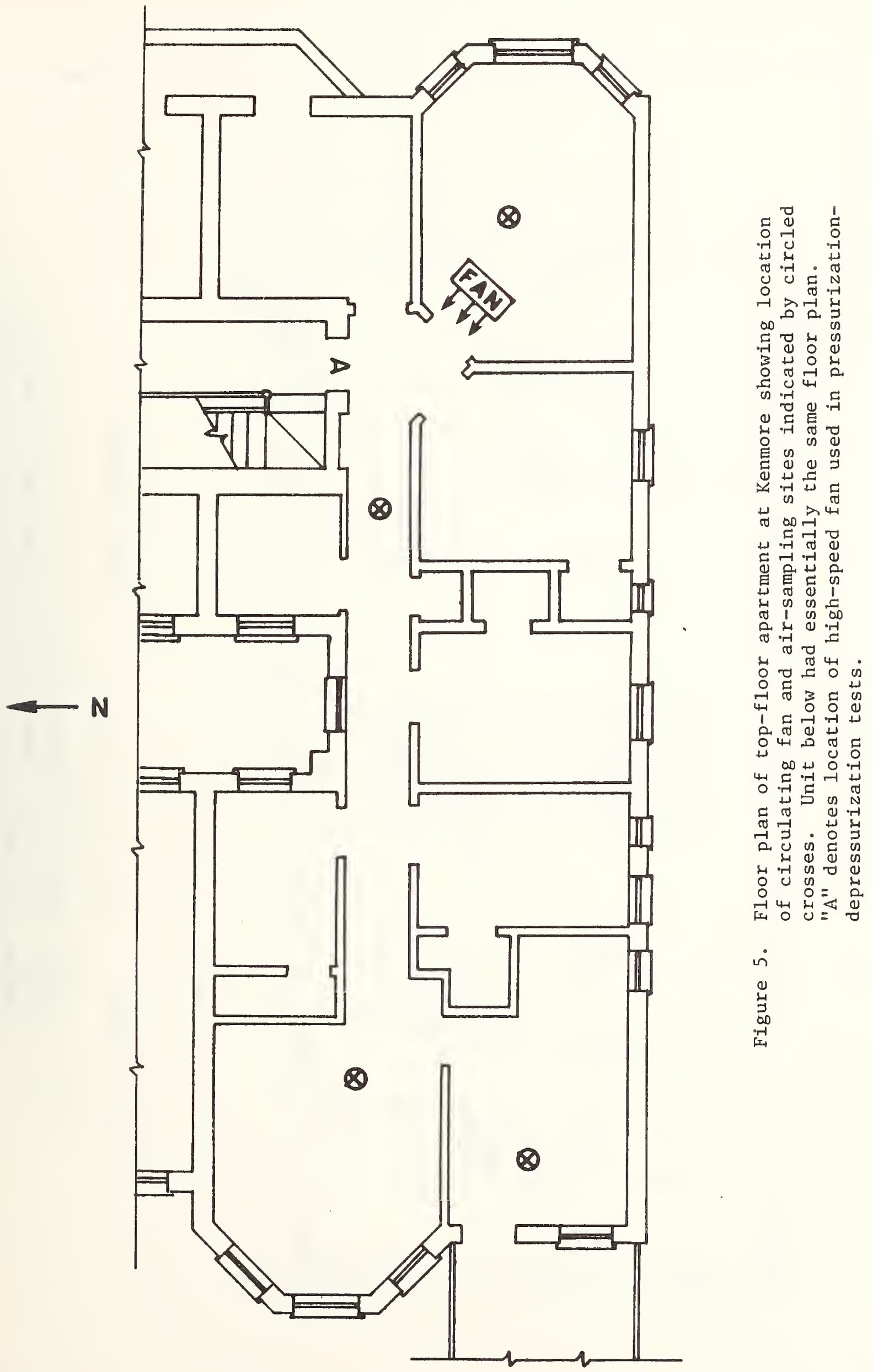



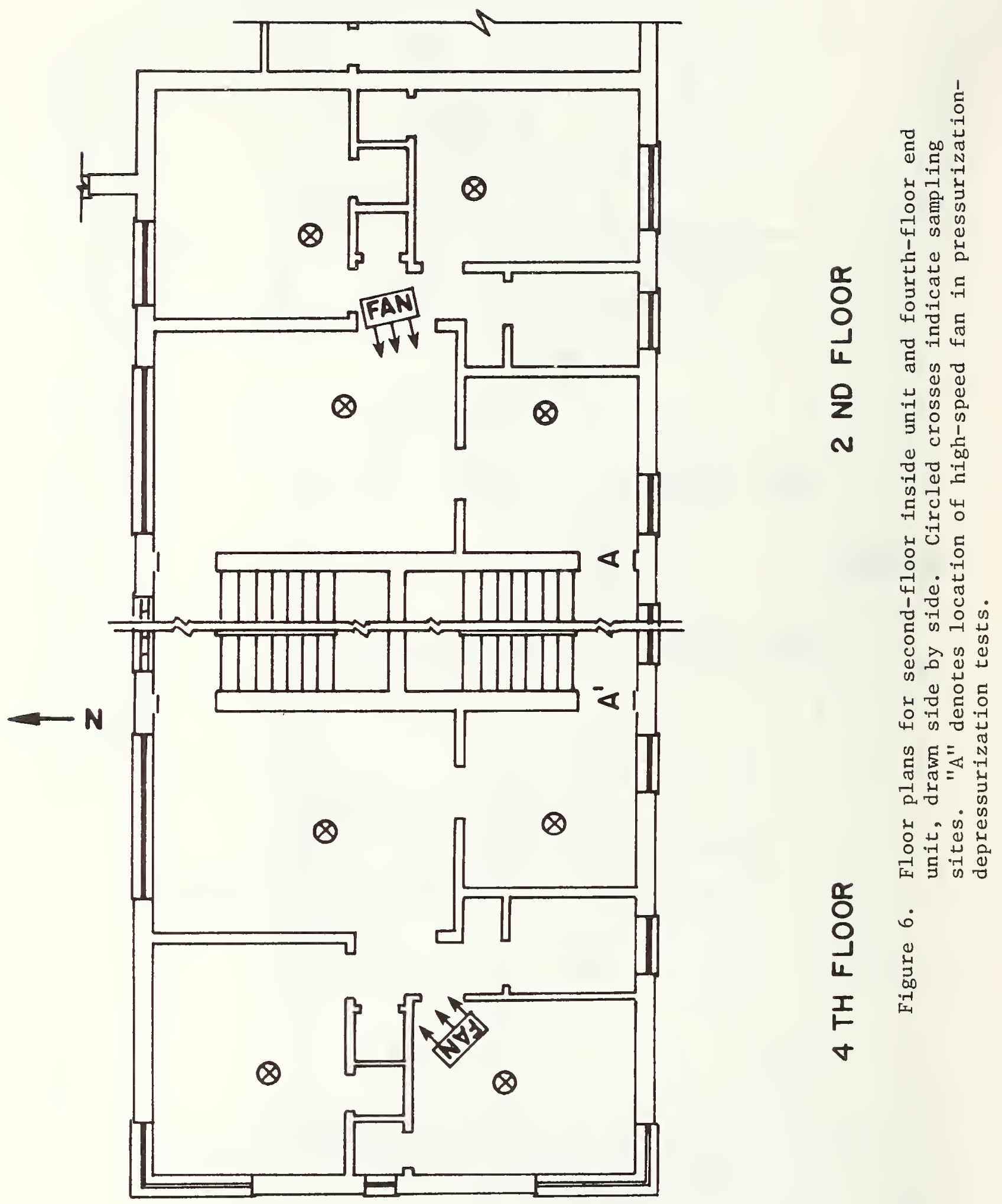


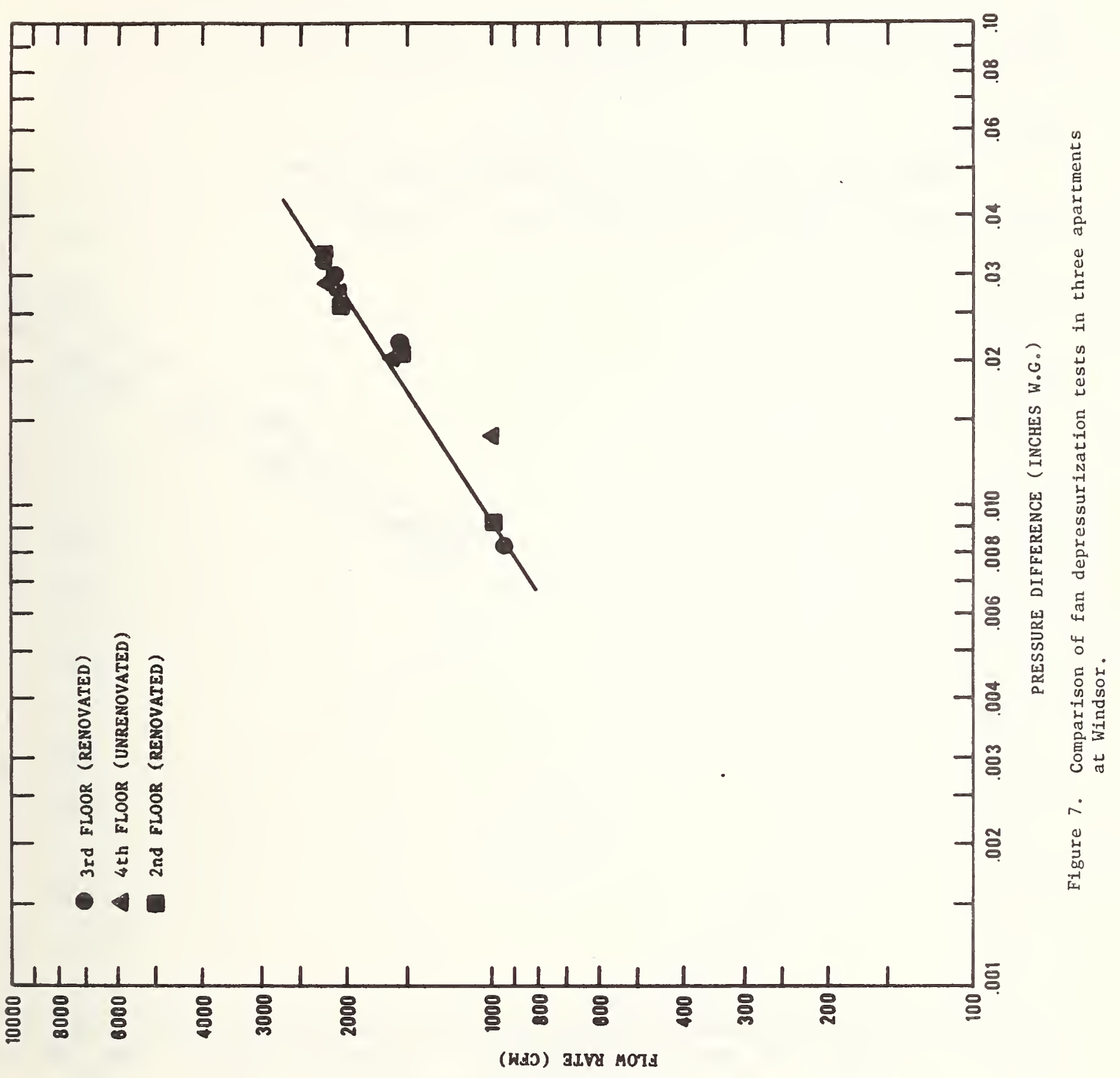




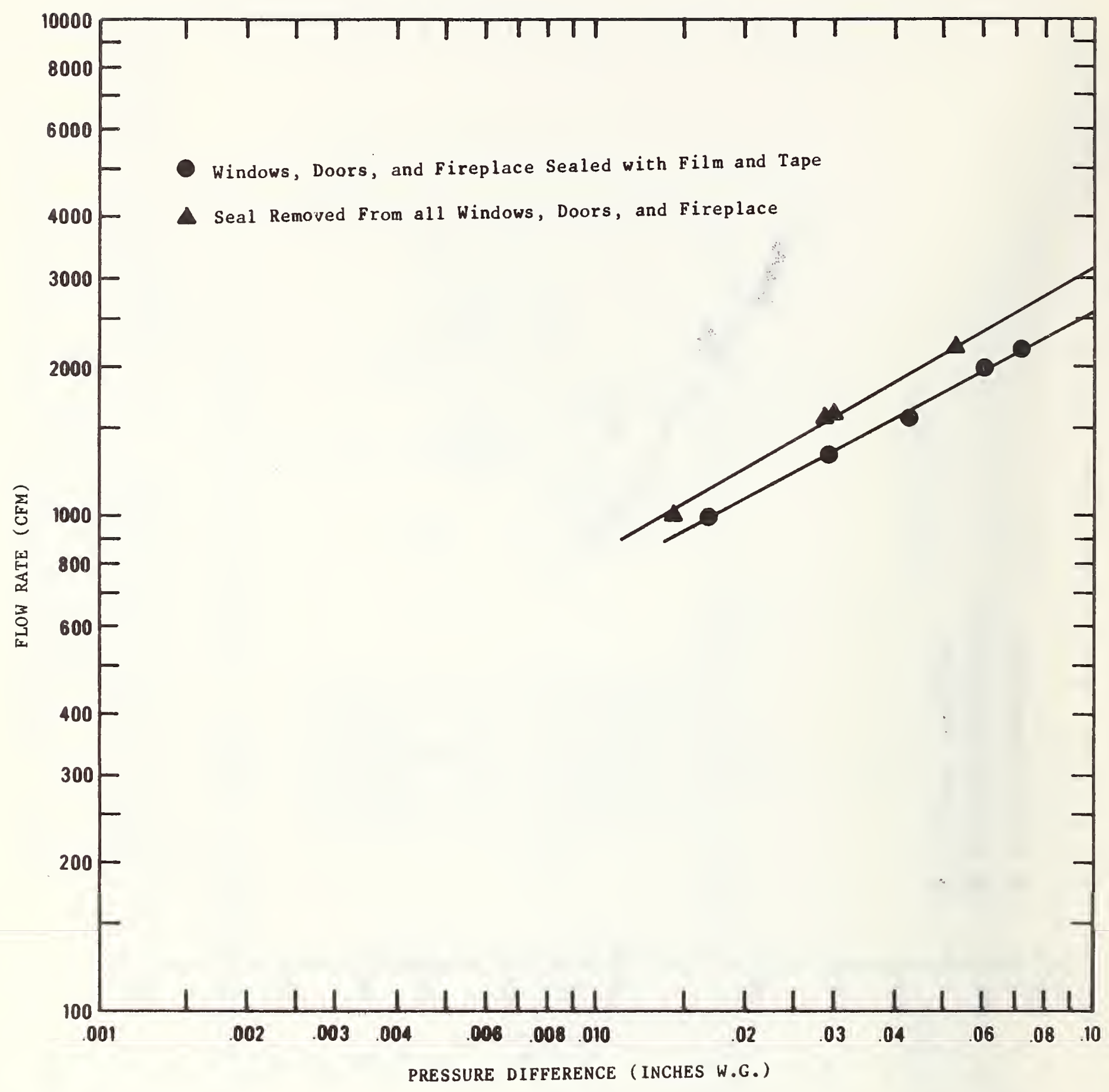

Figure 8. Comparison of fan pressurization tests at Windsor with windows, doors, and fireplace sealed and unsealed. 


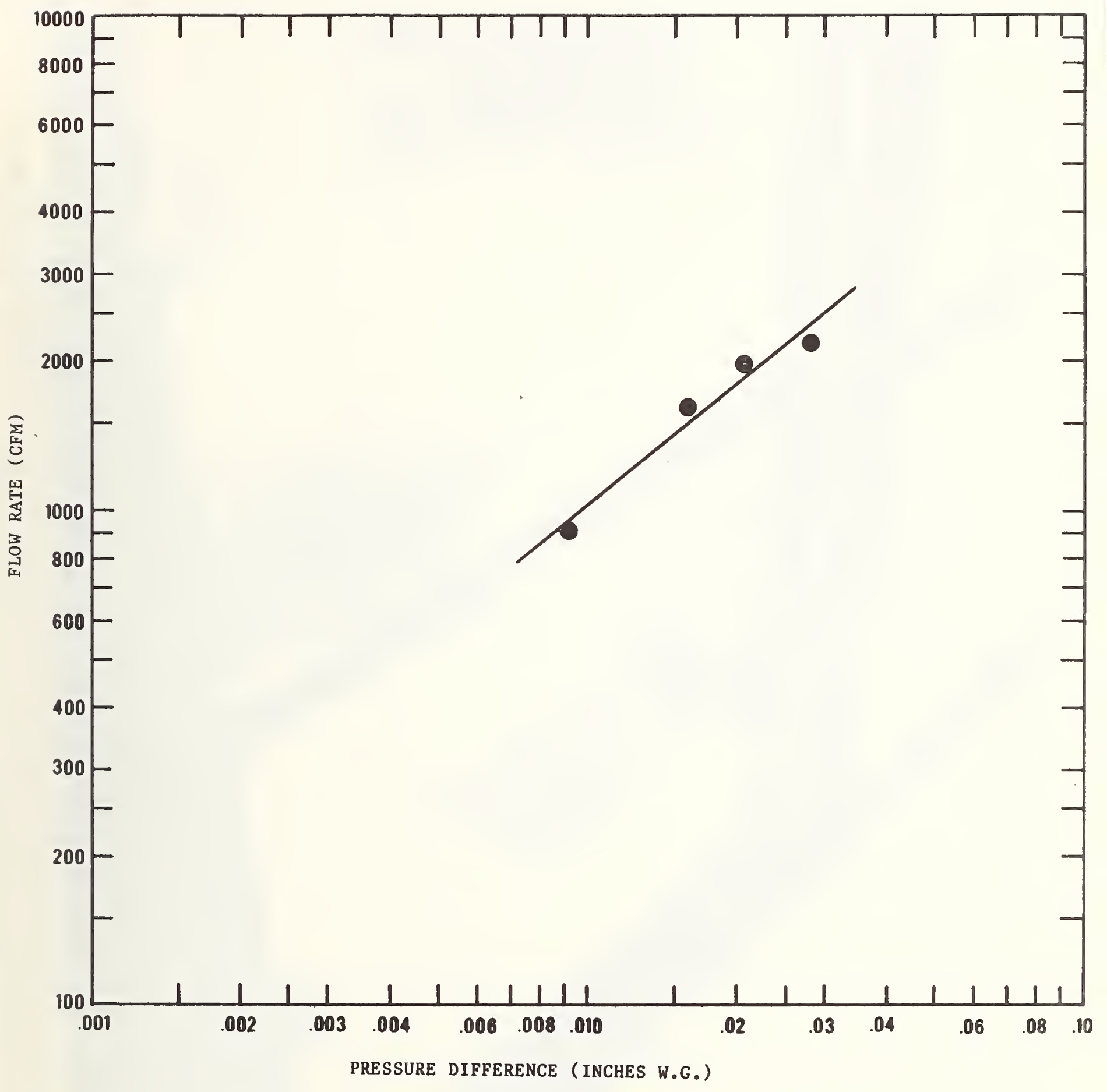

Figure 9. Fan depressurization tests at Kenmore. 


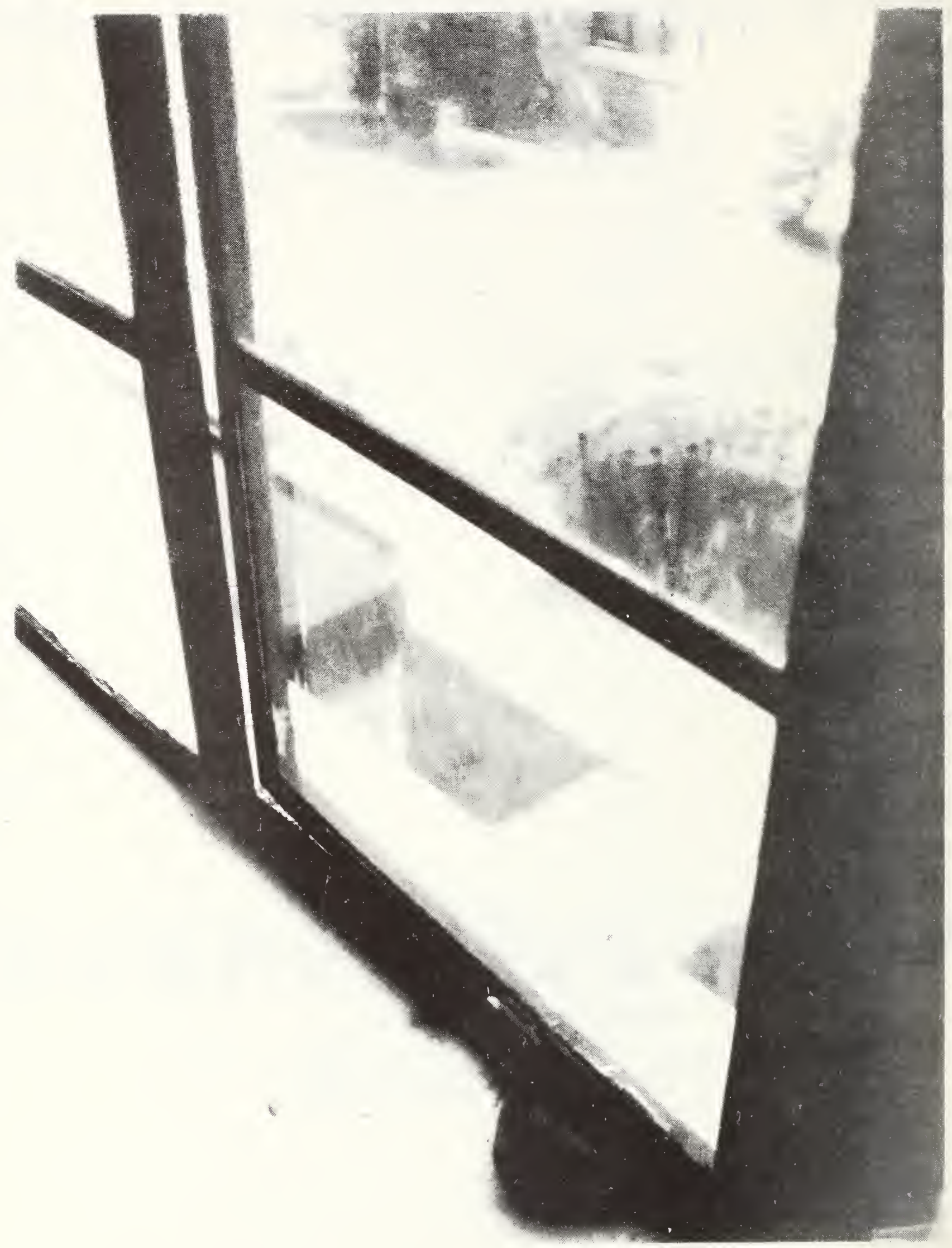

Figure 10. Illustration of a window opened slightly to intentionally produce a leak. 


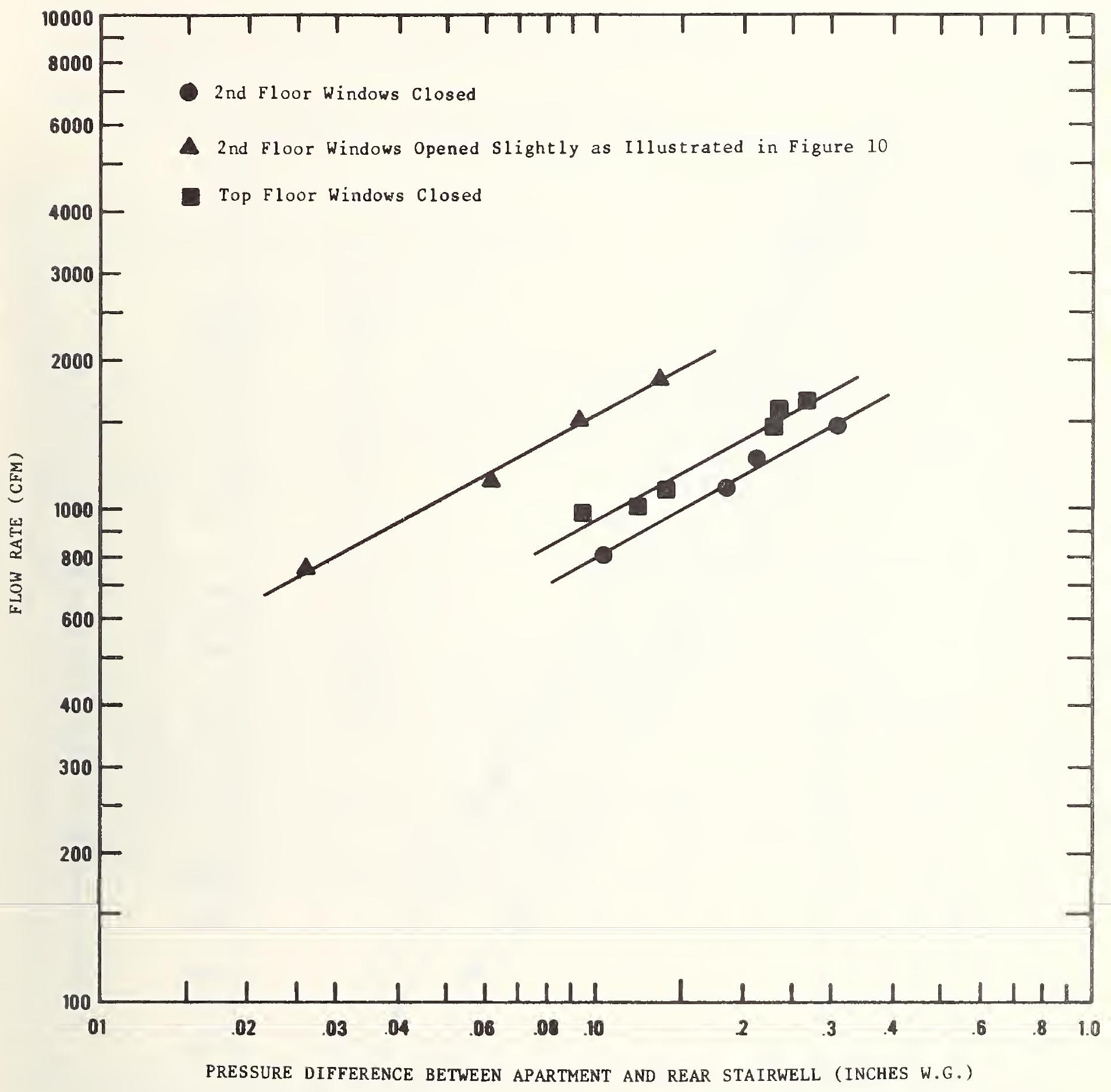

Figure 11. Fan depressurization tests at Custer comparing second-floor interior apartment and fourth-floor end apartment, and also showing the effect of slightly opened windows. 


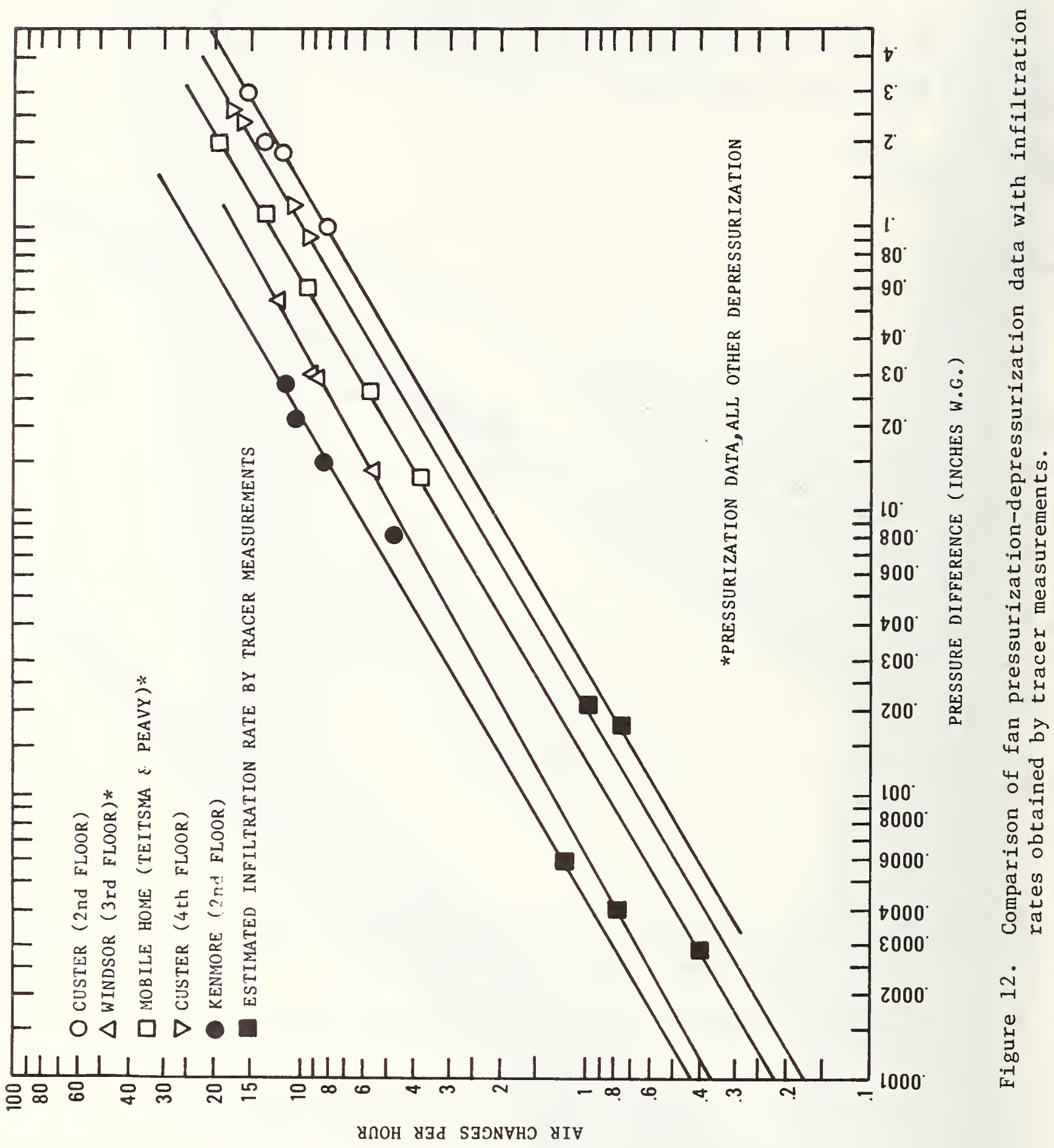


NBS-114A (REV. 7-73)

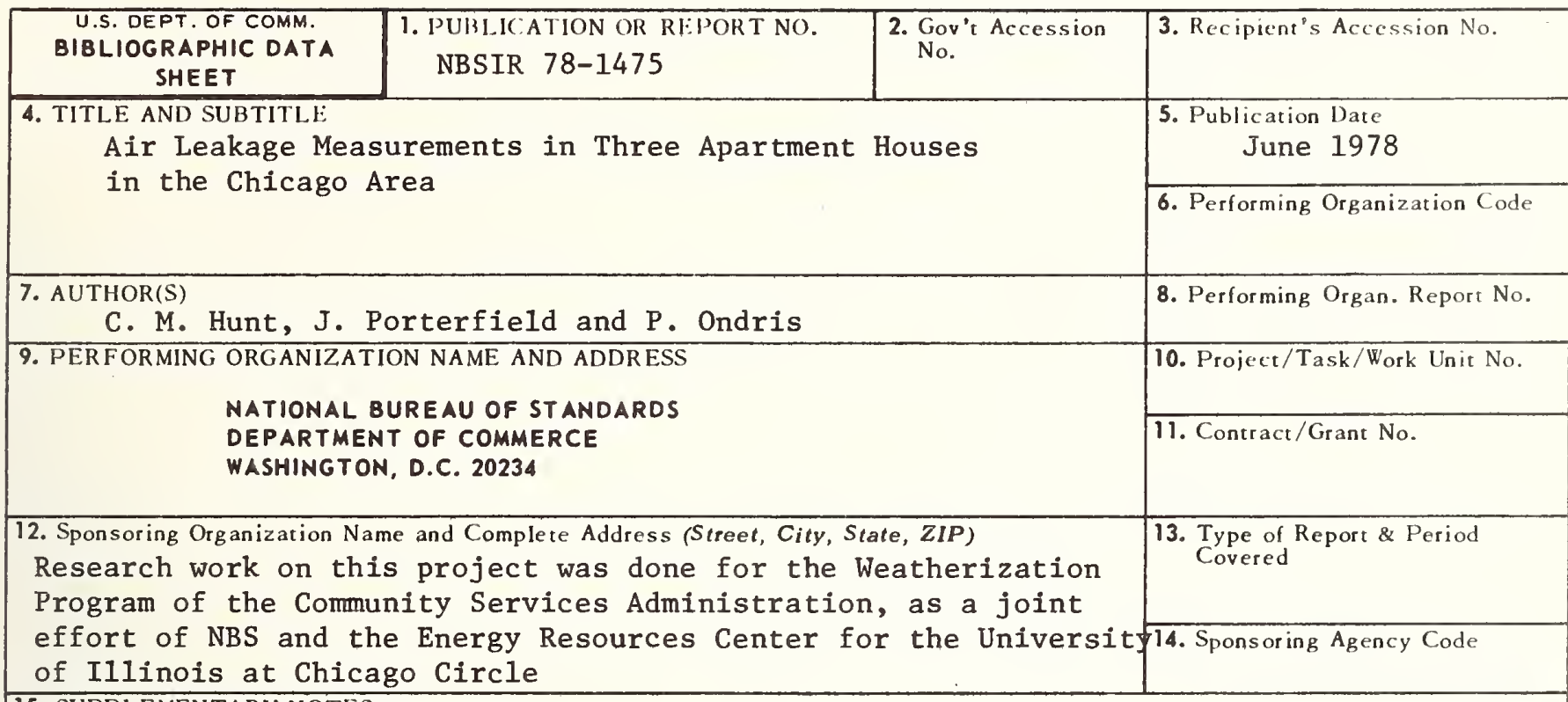

15. SUPPLEMENTARY NOTES

This NBS-funded report will make the results generally available.

16. ABSTRACT (A 200-word or less factual summary of most significant information. If document includes a significant bibliography or literature survey, mention it here.)

Air infiltration measurements were made in three apartment houses in the Chicago area using $\mathrm{SF}_{6}$ as a tracer gas. Two were in tenement districts and one was suburban. Data were collected in selected apartments in each building, and these data were used to estimate the infiltration rate for the entire building. Whole building estimates of 0.94 and 1.2 air changes per hour were obtained under the conditions of tests in the tenement apartments, and 0.82 air changes per hour in the suburban apartment.

Comparisons of the tightness of individual dwelling units by fan pressurizationdepressurization techniques were also made. The suburban apartment was found to be much tighter than the other two apartments. The difference was much greater than predicted by the tracer tests.

An analysis of the ASHRAE Crack Method is also made.

17. KEY WORDS (six to twelve entries; alphabetical order; capitalize only the first letter of the first key word unless a proper name; separated by semicolons)

Air infiltration; air leakage; sulfur hexafluoride tracer, low income housing.

18. AVAILABILITY X Unlimited

$\square$ For Official Distribution. Do Not Release to NTIS

Order From Sup. of Doc., U.S. Government Printing Office Washington, D.C. 20402, SD Cat. No.CI3

X] Order From National Technical Information Service (NTIS) Springfield, Virginia 22151

\begin{tabular}{|l|c|}
\hline $\begin{array}{l}\text { 19. SECURITY CLASS } \\
\text { (THIS REPURT) }\end{array}$ & 21. NO. OF PAGES \\
UNCL ASSIFIED & 27 \\
\hline $\begin{array}{l}\text { 20. SECURITY CLASS } \\
\text { (THIS PAGE) }\end{array}$ & 22. Price \\
UNCLASSIFIED & $\$ 4.50$ \\
\hline
\end{tabular}




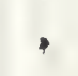

I 
$\bar{y}$
$\bar{x}$
$\frac{1}{x}$
$\frac{1}{n}$ 